\title{
Nietzsche: \\ esculpiendo los sonidos de la aurora
}

\author{
CARMEN PARDO SALGADO
}

\section{DeSDe EL ESPíRITU DE LA MÚSICA}

Nietzsche, el filósofo de extraña voz, escribe su primer libro desde el espíritu de la música. Desde ese espíritu, el filósofo discurre dibujando para la imaginación del lector, también para su entendimiento, cómo tuvo lugar el nacimiento de la tragedia en la música. Un filósofo que sitúe su voz, su lugar de enunciación en la música, no es habitual y, sin embargo, este filósofo recuerda que hubo una vez en que la esencia de la música fue, al mismo tiempo, la esencia de la mundo ${ }^{1}$. El saber se encontraba entonces en esa esencia compartida que Pitágoras descubrió. Un saber que reconocía que las longitudes de las cuerdas en tensión debían encontrarse en la relación de 2 a 1 para ofrecer la octava; de 3 a 2 para la quinta; de 4 a 3 para la cuarta. Y que estos números $(1,2,3,4)$ junto con el producto de su suma (10) podían definir todos los demás intervalos descubiertos por los pitagóricos.

1 KSA VII, 3 [46], Nachgelassene Fragmente 1869-1874. Este artículo prosigue las reflexiones presentadas en las Jornadas Nietzsche 2000. «Nietzsche no ha muerto: entre arte, filosofía y política», organizadas por la Universidad de Buenos Aires del 17 al 22 de octubre de 2000 y en el Coloquio Internacional Nietzsche «Algunos nacen póstumamente», realizado en Valparaíso y Santiago de Chile entre el 23 y el 28 de octubre de 2000. 
La esencia era número, es decir, articulaciones numéricas que engendraban y explicaban el movimiento adecuado, la armonía. Los intervalos musicales, las distancias entre los planetas y, los movimientos del alma, compartirían esa esencia que los acordaba. Por ello, la música sensible era considerada, asimismo, como la expresión de las relaciones matemáticas que gobernaban el cosmos y que otorgaban la justa medida del alma. La música era, por su esencia, una experiencia sensible que estaba atravesada también, por la razón, la proporción. Esta doble vía sería expuesta por Aristógenes de Tarento (370-300 a.C.), discípulo de Aristóteles, quien explicaría que los pitagóricos contaban con un método racional que se contraponía al intuitivo, fundado en los sentidos. Siguiendo esta doblez, los primeros pitagóricos fueron clasificados en acusmáticos y matemáticos. Los primeros serían los que corresponden al ámbito de la praxis y serían no-demostrables, sin logos. El método matemático aparecería en cambio, como un 'dar cuenta' (logos) preciso. La concepción matemática será la que prevalezca y haga de la armonía doria la más estudiada en los círculos pitagóricos, la armonía propiamente griega, como afirmaba Platón².

La proporción hecha razón sonora, era también la esencia del alma humana. Así, el acorde entre música y alma era también sometido a un uso moral. Por ello, la definición de las relaciones numéricas que están en la base de los acordes musicales, se constituían en el punto de partida para descubrir las leyes que regían los sentimientos del alma y los movimientos del universo. Damón de Atenas (hacia 500 a.C.), atendiendo a la influencia que se da entre música y alma, creará una teoría ética en la que la música se convierte en un instrumento de progreso moral basado en la mímesis. Más tarde, Platón, siguiendolas enseñanzas de Damón, sostendrá que el canto y la danza activan el alma. La esencia de la música, número racional y sensible, fue partida en esa doblez tan conocida por la historia de la filosofía. La música no será ya la esencia del mundo para este filósofo griego, pero seguirá incidiendo en el alma humana y, a través de su función educativa, se convertirá en el fundamento de la ascensión hacia el mundo inteligible. Aunque, como es sabido, para este filósofo, la filosofía se ha convertido en la música más excelsa.

2 Acerca de la relación entre música y filosofía en la antigüedad es particularmente interesante la obra de Johannes Lohman, Mousikéund Logos, Musikwissenschaftliche Verlags, Stuttgart, 1970. 
Nietzsche recuerda que, una vez, la esencia de la música fue la esencia del mundo, pero no es ya esa esencia ni sus avatares en manos de la filosofía, el espíritu en el que el filósofo asienta su voz. La supuesta inversión del platonismo que el joven Nietzsche realiza, trastocará desde el inicio la afirmación platónica de que la filosofía es la música más excelsa, provocando una fractura en la misma acción del filosofar.

En las armonías que el platonismo teje, la voz de Nietzsche introduce una disonancia. Sus palabras no se tensan siguiendo el compás de la dialéctica, esa música numerada que al filósofo griego gustaba practicar. Con esas melodías era posible activar la reminiscencia, era una música para recordar, los sonidos de una memoria acordada que se orientaba hacia la visión, hacia un tipo de contemplación. Las melodías de Nietzsche en cambio, se componen de otra música. Se trata de unos sonidos que, lejos de contribuir al recuerdo, producirían el despedazamiento. Una música que introduciría en el olvido, la música dionisíaca que Platón denostaba. El espíritu de la música en el que Nietzsche asienta su voz es distinto, puesto que le conducirá a otro tipo de saber, ya no el platónico, pero tampoco el que descubrió el pitagorismo.

Los sonidos que Nietzsche escucha, se alejarán de esos otros que terminaron forjando lo que el filósofo alemán denominó el hombre teorético. Un hombre que en El nacimiento de la tragedia será presentado con la figura de Sócrates, ese ojo ciclópeo fijo en la tragedia. Un ojo al que, según el filósofo, «le estaba vedado mirar con complacencia los abismos dionisíacos»3 . Este ojo privado del entusiasmo artístico, no comprendía la tragedia, no vislumbraba la sabiduría trágica porque su mirada estaba teñida ya por otra visión, por otro saber.

Pero, ¿qué tipo de saber es el que potencia la fijación de un solo ojo y olvida el oído? Ese saber se exponía en las máximas socráticas que Nietzsche recuerda $\mathrm{a}^{4}$

$1^{\circ}$ «La sabiduría consiste en el saber».

$2^{\circ}$ «No se sabe nada que no se pueda expresar y de lo que no se pueda convencer a otro».

3 KSA I, Die Geburt der Tragödie aus dem Geiste der Musik, ep. 14.

4 KSA I, Socrates und die Tragoedie. 
La sabiduría será lo que pueda ser expresado de modo persuasivo. La sabiduría pertenece al orden de la lucha, a un advenir agonal centrado en la argumentación y que, en la dialéctica, encontrará su modelo. El acontecer trágico en cambio, no puede ser expresado verbalmente, ni siquiera visto, por quien no esté habitado por el entusiasmo artístico. La tragedia requiere el entusiasmo artístico para operar una transformación y no una mera visión a distancia. La tragedia no se ofrece a la contemplación que el ojo ciclópeo espera. Por ello Sócrates, se convertirá para Nietzsche en el prototipo del individuo crítico, del espectador crítico que armonizará su voz con el hombre teorético.

El ojo de Sócrates no dejaba espacio a un oído como el de Ariadna, un oído pequeño, tal vez como el oído que Nietzsche emplaza en el espíritu de la música.

El oído de Nietzsche y la voz que resulta, se sitúan en un lugar en el que la visión está vedada. Desde el espíritu de la música el filósofo está en la noche, en lo no plástico, en lo no escultórico. En la escucha de la noche, la mirada del filósofo se tornará sutil y hallará el acorde que permite entonar ese nacimiento de la tragedia, el nacimiento que los sonidos de Sócrates y Platón no lograron ni quisieron acordar, el nacimiento de un saber que fue suplantado por la mirada del cíclope, por la mirada del prisionero que sale de la caverna y aprende a ver. En consecuencia, a la dialéctica platónica que establecía el engarce adecuado de las melodías del alma, se opondrá la gestación del pensamiento trágico, del pensamiento que surge en y con la música dionisíaca. El gesto de Nietzsche, acomodando su voz en la música, bien podría ser entonces, la forma de indicar que existen otras vías del pensar y que hay una música distinta para entonar.

\section{El SABER DE LA DISONANCIA}

La primera obra de Nietzsche interroga el nacimiento del pensamiento a partir y en la música, lo que servirá de bajo de resonancia al resto de su filosofía.

Pero, ¿cómo la música puede dar lugar al pensamiento? Nietzsche expone que la música dionisíaca de la que surge la tragedia, se despliega primero en imágenes, después en caracteres y, finalmente, se 
hace pensamiento trágico5. Este proceso no será solamente la ejemplificación de un acontecer ya olvidado, sino que se considerará también como el vehículo para regenerar la cultura alemana. Por ello, situarse en el espíritu de la música supone a la vez, prestar atención por un lado, a la música de su tiempo y principalmente a la música de Wagner y, por otra parte, a la música dionisíaca como sustrato metafísico que origina lo trágico y le sirve de baremo para la música romántica. Este doble tratamiento, encontraría su punto de unión en la consideración de la música como arte dionisíaco. Sin embargo, a menudo el filósofo deja al lector en la incertidumbre, en la pregunta acerca del tipo de música que el pensador expone.

La música es presentada desde la consideración, si se quiere metafísica, de esa música dionisíaca, y desde la relación que este arte no plástico entabla con el mundo plástico de la palabra. Desde esta doble presentación se analiza la posible consonancia entre ojo y oído. Primero, a través de la música de su tiempo, y después, en el nacimiento de la tragedia. Ambos análisis mantendrán, a modo de bajo sostenido, la pregunta por el resurgir de la cultura alemana.

En un escrito póstumo de la primavera de 18716, Nietzsche analiza la relación entre la música y la palabra. Este cuestionamiento se lleva a cabo desde la referencia a la práctica musical del momento y desde la crítica a la noción de voluntad en Schopenhauer. La consecuencia será el desplazamiento de la noción de voluntad schopenhaueriana, así como la invalidación de la máxima socrática que afirmaba que «no se sabe nada que no se pueda expresar». De este modo, desde la referencia a la música, la noción de voluntad y la de saber se verán alteradas.

En este escrito el filósofo ofrece tres características de la música dionisíaca:

1. La significación de la música es intemporal, eterna.

2. Su origen se encuentra más allá del principio de individuación.

3. La voluntad es su objeto. 
Esta triple caracterización tendría por objeto, en primer lugar, situar la significación musical fuera del tiempo, al abrigo de ese ojo solar que desembocaría en el ojo crítico, en el nuevo papel del crítico musical que empezaba a estar en boga en su tiempo. En segundo lugar, se estaría atacando el uso moral de la música. Situando el origen de la música más allá del principio de individuación, además de aludir al despedazamiento sufrido por Dionysos y a la necesidad de ruptura de ese principio tal y como se presenta en su primera obra, el filósofo evita, al mismo tiempo, la alusión a la percepción de la música como elemento constitutivo de la identidad del individuo. Por último, el hacer de la voluntad schopenhaueriana objeto de la música afirma a ésta como el único fenómeno originario, no plástico y la distingue de la voluntad.

La relación de la música con la palabra, después de lo expuesto, se convertirá en una crítica a aquellos que pretenden equiparar ambas expresiones. Para llevar a cabo su crítica, Nietzsche parte de una cita de Schopenhauer en la que éste se refiere al 'espíritu musical'. En esta referencia se indicaría que, aunque la música no lo requiere, es adecuado para nuestro intelecto, complementar los sonidos con palabras y con las imágenes. Esta concepción, sin duda heredada de la Ilustración y aplicada al drama, será rechazada por Nietzsche, aunque de un modo harto sutil.

El filósofo recuerda que la unión entre la música y la palabra se daba en el mismo origen de la música en tanto música vocal, un origen en el que los nexos entre las palabras y los sonidos aún no se habían quebrado ${ }^{7}$. Pero ese origen dista de las circunstancias que viven la palabra y el sonido en el siglo XIX. Por eso, el filósofo continúa exponiendo la dualidad de la esencia del lenguaje, el hecho que la palabra, en tanto representación, sea ya un símbolo. Las palabras son consideradas como representaciones conscientes o inconscientes y el hombre está condenado a tratar con esas representaciones. Del mismo modo, la vida afectiva, los sentimientos, los afectos, las sensaciones y los actos volitivos, son pensados también como representaciones. Como Nietzsche escribe, «no hay en parte alguna un puente directo» que conduzca a la esencia del Universo, «y puede decirse que hasta la 
'voluntad' de Schopenhauer no es sino la manifestación [Erscheinung] más general de algo por lo demás del todo inescrutable».

La voluntad schopenhaueriana se distancia de la música en tanto fenómeno primigenio y la música misma se convierte en el ejemplo sonoro de la imposibilidad de tender un puente directo con la esencia del Universo. De este modo, la concepción de la música que Nietzsche parece albergar, se alejaría no sólo de las melodías socráticas y platónicas, sino también de la esencia de la música que el pitagorismo identificaba con la esencia del mundo. Si la esencia de la música sigue siendo la esencia del Universo, para el filósofo alemán esta esencia no es ya el número. El abandono del número como esencia, de la filosofía como música más excelsa, y de la voluntad como máximo acercamiento a esa esencia, conlleva también un rechazo del uso moral de la música.

Siguiendo el análisis que Nietzsche realiza de la vida afectiva, se evidencia la crítica que el filósofo realiza a este uso moral. El filósofo parte de los sentimientos de placer y displacer como aquellos que, a modo de 'bajo fundamental' (Grundbass) acompañan al resto de las representaciones. Este acompañar incluye a la palabra, así estos sentimientos se simbolizan en las «modulaciones de la voz de la persona que habla» (Töne des Sprechenden) y se convierten en el 'tono fundamental' (Tonuntergrund). Los sentimientos de placer y displacer son el 'bajo fundamental' del resto del sentir, el sostén desde el que el conocimiento se gesta; la base desde la que, tal vez, se abre o se cierra la pupila socrática. Pero no sólo, porque este bajo fundamental del sentir, indica también el tono del decir, lo que puede ser expresado. El saber socrático sería entonces, aquello que puede constituirse desde un modo determinado del sentir. Ningún hombre podrá escapar a esas determinaciones, no hay un puente directo, pero sin duda tampoco estará obligado a quedarse en el bajo que dicta el sentir socrático, esa mirada que fija en la tragedia se asemeja a una mirada ausente.

El filósofo, con unos presupuestos que lo apartan de la voluntad schopenhaueriana, tanto como de la constitución del saber que da lugar al hombre teórico, y del uso terapéutico de la música que acompañaba a esta formación del saber, pasará a examinar la música de su época. Nietzsche afronta la creación del Lied. Su análisis se centra en la oposición entre la palabra considerada como símbolo, y por ende representación, y la música que, por definición, carece de representa- 
ción. Atendiendo a esta dualidad el filósofo criticará a aquellos que pretenden que la poesía, la palabra, puede originar la música. Así exclama: « ¿Cómo se quiere, empero, que la imagen, la representación, produzca música!». La música puede engendrar la imagen, los caracteres, la tragedia griega en suma, pero la imagen nunca podrá producir la música, sostiene el filósofo.

Sin embargo, la convicción de que la palabra, y concretamente la poesía, puede originar la música, estaba muy extendida entre sus contemporáneos. Se pensaba que un sentimiento común a ambas podía dar origen a la composición.

El rechazo del filósofo a esta posición, se basa en que los sentimientos no pueden ser objeto de la música, sino solamente su símbo1o ${ }^{8}$. El objeto de la música, la voluntad, sería el estado anterior al sentimiento ya determinado, tal vez el bajo fundamental en el que todavía no se ha determinado el sentir que acompañará el resto de las representaciones. No obstante, ese estado no puede ser confundido con la música. Para mostrar la distancia que hay entre la imagen o la palabra y la música, el filósofo examina el modo en que crea el poeta lírico y el músico.

Del poeta lírico se afirma que «transpone ese dominio de la 'voluntad' sustraído al concepto y a la imagen, el contenido y objeto propiamente dicho de la música, en el mundo simbólico de los sentimientos». La transposición de la voluntad indeterminada al simbolismo de los sentimientos, se realiza solamente cuando el poeta está sumido en la visión apolínea, sustraído al mundo de los afectos. En El nacimiento de la tragedia esta visión, que es la socrática, se presentará como «un ojo solar puro y no turbado»9. Esta caracterización que el filósofo utiliza en su primera obra, es pues la misma que se usa para aludir a la creación de su tiempo.

El poeta lírico se caracteriza en ambos escritos por tener una visión solar, apolínea. Este poeta se asemeja, según Nietzsche, al oyente que siente «la música obrar sobre sus afectos» conduciéndole a un

8 El simbolismo del sonido, el sentimiento, es explicado por Nietzsche como un proceso en el que por un ejercicio de repetición de una gran cantidad de sonoridades, la sensación es fijada. A esta fijación contribuiría el texto en el caso de la música vocal. Cf. KSA VII, 3, [13].

9 KSA I, ep. 6. 
reino intermedio. Desde aquí, el sentimiento que se excita con la música, así como la visión solar, es tan solo el camino medio que se dibuja entre la representación de la palabra y lo irrepresentable de la música.

El compositor en cambio, es guiado por una excitación musical, a-representativa, que le conduce a escoger su texto en tanto 'expresión alegórica' de esa excitación. De este modo, a la serenidad apolínea se opone la excitación musical que puede vertirse en sonido y palabra en tanto expresión alegórica, o quedarse en sonido puro. No obstante, pocos son los compositores que verdaderamente parecen dejarse guiar por la excitación musical. En muchos casos se asiste a un rebajamiento de las fuerzas creadores cuyo máximo exponente es, en este texto, la música dramática.

La música dramática es aquella que ya no es capaz de obrar de forma dionisíaca sobre el oyente. En ella, los sonidos se convierten o en retórica convencional, o en música excitación, música fisiológica. En el primer caso, el sonido es tan sólo un signo que debe llamar la atención sobre la imagen. La segunda, sería la que ejemplificaría el uso moral de la música que el filósofo había rechazado.

El lazo primigenio que existió entre los sonidos y las palabras se quebró, como también se quebró cuando se produjo la muerte de la tragedia. Por ello, desde una palabra reducida a símbolo, a mera representación no se puede pretender originar el sonido, ni siquiera asemejarse a ese mundo de lo a-representativo.

El nexo adecuado entre la música y la palabra consistiría entonces en lo trágico, en una «elucidación (Verdeutlichung) apolínea de lo dionisíaco»10. Esta lucidez será la que se exponga en El nacimiento de la tragedia, donde la potencia de la música dionisíaca dará lugar a la tragedia, a esa mediación entre Apolo y Dionysos.

En su primera obra la caracterización de la música dionisíaca también encuentra ecos en la música de su tiempo. El filósofo, haciendo referencia al placer que comparten el mito y lo dionisíaco equipara este placer al que produce la disonancia en la música, un placer que sería percibido en el dolor. En ese oír y desear ir más allá del oír, mirar y anhelar atravesar la visión, se situaría el efecto del mito trágico. Esta 
doble pulsión en la que placer y dolor forman un mismo sentimiento, sería sentido por el espectador que ha dejado que fluya lo trágico. Se trataría quizá de la doble pulsión que da nacimiento a la tragedia, al modo en que Apolo y Dionysos se van a solicitar para la creación del pensamiento trágico.

La necesidad de la mediación vendría dada por el carácter arepresentacional de la música dionisíaca. La consecuencia de esta posición será la consideración de que la música dionisíaca, el arte dionisíaco por excelencia, no tiene oyente; el «extático adepto de Dionysos sólo es entendido por quienes se hallan embargados por el mismo estado anímico que él». Esta afirmación, realizada en el texto póstumo de la primavera de 1871 , se mantendría en su primera obra. El estado que encontraría en el extatismo no podría pertenecer a la escala del oír ni el sentir humanos. La necesidad de la mediación, de la creación de la visión, sería la consecuencia de la imposibilidad de la escucha, de la ausencia de un oyente. En esta mediación se encontrarán dos mundos a los que corresponden sendos estados: un estado musical y otro no musical. El filósofo alude en consecuencia, a dos modos de estar, de hacer mundo y en el caso del hombre, de abordar el conocimiento de este mundo y de sí mismo.

La mediación produce la tragedia. Nietzsche partirá del coro como elemento fundamental en la creación de la tragedia. Así, establecerá los nexos entre el coro y la visión, la oposición entre el coro de sátiros y el hombre civilizado y, posteriormente, los lazos entre el coro y la escena.

El origen de las visiones que se proyectan sobre la escena y, por tanto, el origen de la tragedia, lo sitúa el filósofo, como es sabido, en el coro de sátiros. El coro de sátiros se afirma «es ante todo una visión tenida por la masa dionisíaca»11. La masa dionisíaca se creería transformada en sátiro. En esta transformación, el individuo perdería la representación de sí mismo, su fijación al tiempo que se difuminan los límites que ofrecen la imagen del mundo.

El coro de sátiros representa, para el hombre griego esbozado en El nacimiento de la tragedia, la imagen primordial del ser humano. En él se habrían revelado los instintos de la naturaleza y su transforma- 
ción en sátiro se acordaría con la manifestación de sus emociones más altas y fuertes. El sátiro se correspondería en esta obra, con la imagen del hombre natural no sujeto por las redes de una cultura que anula su capacidad simbólica convirtiéndola en mero signo, en débil expresión de una fuerza. En esa transformación mágica, el coro, a su vez, proyectará una visión fuera de sí, que constituirá el mundo de la escena, en la que las máscaras nos dan los caracteres. Y, finalmente, la escena pasa a ser simbolismo del baile, la música y la palabra. Se termina con ello el proceso que ha hecho posible que la música dionisíaca infante la tragedia, origine el pensamiento trágico.

El pensamiento trágico sería entonces la obra coral que abre un espacio que no se correspondería con el que percibe el ojo ciclópeo, ese ojo solar falto de entusiasmo artístico. El pensamiento trágico sería quizás, espacio dado a una mirada que se sabe atravesada por la escucha. El pensamiento habría sido dotado de otro tiempo y otro espacio. Este pensamiento enuncia, como es sabido, que sólo como fenómeno estético está justificada la existencia. En consecuencia, el fenómeno estético no puede ser juzgado ya desde un conocimiento discursivo que lo relega a conocimiento confuso. El fenómeno estético es el máximo conocimiento que el hombre, que ha comprendido la necesidad de Apolo y Dionysos, de la conciliación de un estado plástico y uno musical, es capaz de forjar.

Recuérdese al respecto el inicio de esta obra: «Mucho habría ganado la ciencia estética si hubiéramos alcanzado no solamente la comprensión lógica sino la inmediata certeza intuitiva de que el entero desarrollo del arte está ligado a la dualidad de lo apolíneo y de lo dionisíaco como, análogamente, la generación — en el combate perpetuo donde la reconciliación no interviene jamás mas que de forma periódica- depende de la diferencia de sexos». Mucho habría ganado la ciencia estética si hubiera comprendido que en arte no es suficiente con un solo modelo, que un modelo no explica el por qué de ese conocimiento que Baumgarten, siguiendo a Leibniz, denominaba conocimiento confuso. Mucho habría ganado la ciencia estética si, su fundador, no hubiera sentado sus bases sobre el modelo que le ofrecía la retórica, es decir, si no hubiera continuado acaso el estetismo socrático que el ojo solar contribuyó a formar. 


\section{LOS SONIDOS DE LA AURORA}

El nacimiento del pensamiento desde el espíritu de la música conduce al filósofo a considerar las relaciones entre música y filosofía. La filosofía debía virar y seguir el camino iniciado ya por la música alemana, su despegue del idealismo ilustrado.

La íntima relación entre la música y la filosofía del momento se hacen explícitas en los textos póstumos de 1871. Allí, en unas notas que son pensadas para el prefacio de su primera obra escribe: «Los caracteres de nuestra música y de nuestra filosofía se responden: las dos rechazan el mundo del beneplácito, de las bondades originarias» 12 . Con esta afirmación, Nietzsche critica no sólo el ideal surgido de la Revolución Francesa, sino también el pensamiento ilustrado tal y como es representado por Rousseau. El filósofo francés bien podría ser el máximo exponente de ese idealismo en el que música y filosofía también estaban unidos. Pero la crítica a ese hombre originario apuntaría asimismo, a la esencia del Romanticismo. Recuérdese al respecto la recuperación-invención de las leyendas medievales y la referencia a lo popular y a la imagen del niño como lugar originario. En este sentido el filósofo escribe: «El error fundamental: se piensa el hombre ingenuo original como en la pasión deveniendo músico y poeta: como si las pasiones pudieran engendrar obras de arte» 13 .

La crítica a un cierto Romanticismo se ampliará a todo el Romanticismo y a la música de Richard Wagner más tarde ${ }^{14}$. En los póstumos de 1887-1888 el filósofo se pregunta: «¿Por qué la música alemana culmina en la época del romanticismo alemán? ¿Por qué falta Goethe en la música alemana?»15. Con estas cuestiones el filósofo indicará el extravío que para él supone la ausencia de Goethe y la adscripción de la música alemana al Romanticismo. Nietzsche se refiere al viraje de Wagner hacia el misticismo católico, lo que se encontraba en sintonía con el gusto por las leyendas románticas. El dra-

12 KSA VII, 9 [26] y [132].

13 KSA VII, 9 [137].

14 No obstante, a pesar de que la primera obra de Nietzsche está dedicada al músico, el filósofo había iniciado ya su distanciamiento del maestro. Cf. KSA VII, 12 [1] donde el filósofo realiza la referencia a la música absoluta.

15 KSA XIII, 11 [315]. 
ma musical de Wagner será considerado en consecuencia, como un retroceso, como «una forma decadente de la música» 16 . De este drama se afirma que «ha sacrificado toda musicalidad, la música misma, para hacer un arte de la expresión, de la acentuación forzada, de la sugestión, de lo pintoresco desde el punto de vista psicológico» 17 . La crítica del filósofo radicaría en ese convertir a la música en arte de la expresión, de hacerle decir e introducirla con ello de nuevo en un ámbito psicológico que conducirá a un uso moral. La música de Wagner representa entonces, la decadencia de la música alemana, al tiempo que traicionaría el ideal que guió a la concepción de la música en los orígenes del Romanticismo ${ }^{18}$.

Pero el filósofo también se pregunta por la ausencia de Goethe. Se trata de una pregunta que ciertamente sorprende, ya que la presencia de Goethe en el desarrollo del Lied no podía ser ignorada por Nietzsche. Él mismo, en sus propias composiciones musicales, parece seguir la prescripción goethiana de realizar pocos melismas y ornamentos melódicos. Por lo tanto, al referirse a esta ausencia, Nietzsche estaría criticando la preferencia de los músicos alemanes por escritores románticos y el olvido de los escritos de Goethe, que eran considerados como teñidos por un cierto clasicismo. Los temas de los escritores románticos habrían contribuido además, a la degeneración de la música alemana, a esa introducción del simbolismo de las pasiones que traerían de nuevo los ideales roussonianos.

Esta visión de la música romántica de su tiempo y, en concreto, su despegue de la música wagneriana, aparecía en su «Ensayo de autocrítica» (1886) a El nacimiento de la tragedia como una oposición entre la música romántica y la música dionisíaca. La primera sería

16 KSA XIII, 11 [32].

17 Ibid.

18 La música, y especialmente la música instrumental, era concebida durante el Romanticismo como el vehículo privilegiado de lo inefable. E.T.A. Hoffmann, en referencia a la música instrumental, afirma en 1813: «es la más romántica de todas las Artes —uno casi puede afirmar incluso que es la única genuinamente romántica-, ya que su única materia es el infinito. La lira de Orfeo abrió las puertas de Orcus — la música revela el dominio de lo desconocido, un mundo que no tiene nada en común con el mundo exterior y sensual que le rodea, un mundo en el que abandona detrás suyo todos los sentimientos determinados para rendirse al anhelo de lo inexpresable». Esta referencia a lo inexpresable y a la infinitud conduce a la distinción plenamente romántica entre lo plástico y lo musical. 
considerada como un narcótico que a la vez embriaga y obnubila. El tipo de embriaguez que aportaría la música romántica, a diferencia de la música dionisíaca, no engendraría una visión, sino que oscurecería, anublaría.

Al mismo tiempo, la relación que el filósofo establece entre música y filosofía hace también que la oposición antes señalada se desdoble en otra que afecta al pensamiento romántico y al pensamiento trágico. En el primero, los estados extremos de la embriaguez, en la que se reconocería un síntoma de fuerza, produce la imitación de «formas expresivas» 19 pero no por abundancia sino por carencia de ellas. En el pensamiento trágico la embriaguez se descargaría en imágenes, caracteres y pensamiento mismo, no por carencia de fuerza sino por exceso. En el pensamiento trágico la abundancia de la fuerza conduciría a las nuevas formas expresivas cuya ejemplificación primera sería la tragedia.

En este ensayo el filósofo se recrimina el tono Sturm und Drang que su libro de juventud poseía, y aunque no reniega de su objetivo, «examinar la ciencia con la óptica del artista, y el arte con la de la vida», afirma que su libro no está bien escrito. La obra aparece desde este ensayo, como una 'música' que sólo es oída por aquellos que ya están iniciados en la música. Pero esta música no está bien conducida. El filósofo critica su carácter altanero, y también su carácter discursivo, considerando que esta obra necesitaba si no el canto, al menos la poesía o la filología, un ámbito que aún espera grandes descubrimientos.

El descubrimiento de la potencia que encierra la filología se explicita en el prólogo a Aurora de 1886. Ese reconocimiento, entonces ya realizado, no significará que la música como seno del pensamiento haya sido abandonada, sino que el modo en que ese espíritu se hace forma expresiva en Nietzsche va a ser modificado. Después de $E l$ nacimiento de la tragedia, después de la crítica a la voluntad schopenhaueriana y el progresivo desmarque de las posiciones wagnerianas, Nietzsche, el filósofo de voz extraña, también modificará su modalidad expresiva. Sus escritos han pretendido quizás, alejarse de ese discurrir que ha criticado en su primera obra y se presentan como flechas, aforismos, sentencias... Formas que no siguen un orden que puede 
emular el caminar, sino que precisan el salto, el baile. Se trata de formas que apelan a otro modo de hacer sonar la música, que muestran el ruido. Serían quizás las formas que surgen con los golpes del martillo que empuña el filósofo.

En su «Ensayo de autocrítica» el filósofo aún se pregunta cómo tendría que estar hecha una música cuyo origen fuera dionisíaco y, seguramente, no existe tal música para el oído humano. El mismo filósofo había señalado que el hombre dionisíaco no tiene oyente. Tal vez, lo máximo que se puede lograr, sea un acercamiento fingido o querido a un origen que parece encontrarse en un ejercicio de desfondamiento, un ejercicio que, si fuera posible, iría más allá de ese bajo fundamental que indicaba el tono del decir. Quizás fuera este el ejercicio del filósofo que quiso convertirse en el no escultor, que quiso forjar con el pensamiento y con la palabra un arte dionisíaco.

Filosofar con el martillo sería ahora el modo en que se hace factible el camino hacia el conocimiento trágico, el conocimiento más difícil. Por ello, el martillo se identifica para Nietzsche con Dionysos, en la propuesta de una filosofía del eterno retorno que el filósofo pretendía escribir ${ }^{20}$. Los golpes del martillo bien podrían ser los sonidos de la música dionisíaca que el romanticismo alemán ahogó. Los sonidos del martillo, podrían constituir los nuevos sonidos de una filosofía que se mantiene aún en el espíritu de la música, pero que ya no coloca sus esperanzas en los sonidos de la música alemana. Filosofar con el martillo tal vez sea la labor del filósofo que no esculpe, del filósofo que sigue apegado a un arte no escultórico, aun cuando la palabra sea su modo de transmisión. Nietzsche enseñaría con ello, que la filosofía, el filosofar, exige saber usar el martillo, aprender a quebrar las durezas, las falsos suelos de un pensar que, tal vez, fue el fruto de la mirada de un cíclope, de un pensar que en definitiva, surge sólo del ver y no del escuchar.

Filosofar con el martillo quizás consista en crear la palabra al tiempo que se destruye su fundamento, recordando que para ello se debe ser fuerte. Porque, cuando habla el martillo, sólo se escucha: «haceos duros» 21 . La filosofía que surge del martillo sería una moda-

20 KSA XI, 34 [191], Nachgelassene Fragmente 1884-1885.

21 KSA IV, Also sprach Zarathustra. 
lidad expresiva que brota de la abundancia y no de la necesidad, no sería ya una filosofía romántica, sino plenamente dionisíaca. Por ello, el martillo compartiría con la música la exigencia de un aligeramiento, ambas pedirían al cuerpo el ser ligeros ${ }^{22}$. El filósofo que empuña el martillo está todavía en el seno de la música, de unos sonidos que empujan a la creación por sobreabundancia, que convierten la escritura en un ejercicio calculado para «deshacerse de los pensamientos» 23 . Este deshacerse de los pensamientos, sería el acto que hace efectico el conocimiento como creación, tal y como se expone en la segunda parte del Zaratustra. Allí se lee:

«También en el conocer tan sólo siento el deleite de crear y ser creado que experimenta mi voluntad; y si mi conocimiento es inocente, lo es porque es voluntad de crear.

Esta voluntad me ha apartado de Dios y los dioses. ¿Qué habría de crear, si hubiese dioses?

Hacia el hombre me empuja siempre de nuevo mi ardiente voluntad de crear; así el cincel es empujado hacia la piedra.

¡En la piedra, oh hombres, duerme una imagen, la imagen de mis imágenes! ¡Ay, tiene que dormir en la piedra más dura y fea!

Cruelmente golpea su prisión mi cincel. De la piedra se van desprendiendo pedazos; ¿qué me importa?

Empeñado estoy en dar cima a la obra; pues se presentó ante mí una sombra - ila más queda y sutil de todas las cosas se presentó ante mí!

La belleza del superhombre se presentó ante mí como sombra. Oh hermanos iqué me importan desde entonces — los dioses!

Asíhabló Zaratustra»24.

El creador maneja el martillo que destruye y el cincel que esculpe, ambas herramientas serían necesarias para la creación de conocimiento. Zaratustra sabría que su deseo de esculpir la imagen surge del atisbo de una sombra. Platón quizás no lo supiera nunca. A las melodías platónicas se sigue oponiendo el sonido del martillo y el cincel que crea por sobreabundancia, pero esos sonidos requieren una nueva escucha. La filosofía nietzscheana nacida desde el espíritu de la música reclamará entonces otra escucha, un oyente que no forme filas

22 KSA III, Die fröhliche Wissenschaft, af. 368.

23 KSA III, af. 93.

24 KSA IV, «Auf den glückseligen Inseln». 
con el espíritu crítico, que no sea un mero espectador solar. Este oyente se correspondería tal vez con una filosofía que, plenamente consciente de su voluntad de crear, de forjar apariencias, se instalaría en el momento en que la luz y la sombra se encuentran, en la aurora.

En un texto póstumo de 1881 la música es definida como el arte de la aurora, y es en el prefacio a la obra que lleva este nombre donde el filósofo insistirá en la escucha de su pensamiento. Si se atiende a los epígrafes primero y último de este prefacio, se destaca el modo en que Nietzsche inicia el texto: «En este libro se ve trabajar a un 'subterráneo', a uno que perfora, cava y socava. Se lo ve, siempre que se sea capaz de ver tal trabajo subterráneo, avanzar en forma despaciosa y reflexiva, con suave implacabilidad, sin que se haga mayormente patente el sufrimiento que trae consigo toda privación prolongada de luz y aire; pudiera hasta decirse que está contento con su oscuro trabajo». El lector verá en el libro a un ser de las profundidades, a un ser sin ojos. El lector ve a un ser que trabaja en la oscuridad. Pero, para observar el trabajo de ese ser, el lector deberá también acostumbrarse a la oscuridad, seguir primero a ese topo que cava y socava.

Qué diferente este inicio de aquel otro en que un filósofo decía al lector: «Imagina una caverna subterránea...» y en aquella situación el lector debía aprender a ver acostumbrándose a la luz. No sabemos si la propuesta de inversión del platonismo que el joven Nietzsche proyectaba se hizo factible. No podemos olvidar que los golpes de martillo mostraron que si se quiebra el mundo verdadero también se destruye el aparente. Pero lo que si podemos saber es que el ejercicio que este filósofo alemán propone, requiere cuando menos, la actitud inversa a la que el filósofo griego instaba. Ambos, ciertamente, tienen en común el avance lento, prudente y reflexivo, pero es un recorrer que nos emplaza a situarnos en parajes completamente disímiles. Si el filósofo griego conduce a esa mirada imposible que se levantaría hacia el sol, Nietzsche se adelanta a la desconfianza o a la esperanza del lector que lo ve y que esperaría llegar tal vez a una iluminación, y así, él mismo pregunta si acaso ese empeño que pone el trabajador de la oscuridad, de la caverna quizás, no espera una «redención, una aurora muy suya?...»

Los puntos suspensivos permitirán al lector imaginar, soñar quizás su propia aurora. Pero el filósofo subterráneo anuncia que, cuando haya vuelto de las profundidades, cuando se haya «otra vez 'hecho 
hombre'» dirá lo que buscaba. El filósofo-topo dirá libremente sin ser preguntado porque, en la profundidad, escribe Nietzsche, se «olvida completamente el silencio». Después de tanta soledad y oscuridad, la sonoridad de la palabra bien podrían ser los sonidos que el filósofo arrancó a la noche, los sonidos de la aurora del pensador. El resto del prefacio es conocido, el filósofo expone lo que buscaba: «socavar la fe en la moral». Y ese ejercicio en las profundidades no necesita revelarse con una voz atronadora, una voz queda es suficiente para el que sepa oír.

El último epígrafe del prefacio se inicia con esa voz: «Y para terminar: ¿por qué deberíamos decir lo que somos, lo que queremos o no queremos con voz tan alta y con tanto ardor? Considerémoslo con más frialdad, distancia, inteligencia, altura, digámoslo como puede ser dicho entre nosotros, tan discretamente que el mundo entero no lo escuche [überbört], que el mundo entero no nos escuche! Sobre todo, digámoslo lentamente...» Aquello que el filósofo ha dicho y lo que va a decir en la obra, está entonado con una voz que surge de la distancia de la profundidad, del frío, de la altura de una inteligencia que radica en el excavar. Lo que debe decirse se ajustará al tono de otro sentir, apenas perceptible, apenas para la escucha 25 .

El filósofo que fue topo, no hablará para aquellos que se han formado sobre el querer de las urgencias sordas, absurdas. El excavador no escribirá para los que en la segunda Consideración Intempestiva confundían la cultura con los ruidos del indigesto saber. La lentitud será el nuevo tempo de la escucha; el tempo lento indicará otro modo de hacer, de pensar. El tempo lento responde a esa otra forma de expresión que será la del filólogo, el descubrimiento de ese otro amante del logos. Un amante que enseñaría a hacer la digestión a todos aquellos hombres apresurados que el filósofo mostró; un amante que sólo quiere ya dirigirse a los que sepan escuchar una voz tan queda, a los que aprendan a ver en la oscuridad.

Si El nacimiento de la tragedia era el libro que entonaba ese filósofo de extraña voz, este prefacio nos habla ya de un filósofo que aprendió que su voz sonaba demasiado estridente para los oídos no iniciados, y que sintió la necesidad de enseñar primero a leer. Así, las últimas

25 Recuérdese el aforismo 216 de La gaya ciencia: «Peligro en la voz. - Con una voz fuerte se es casi incapaz de pensar cosas sutiles». 
líneas de este prefacio se anclan en la filología: «ella enseña a leer bien, es decir lentamente, profundamente, mirando prudentemente detrás y delante, con segundas intenciones, con las puertas abiertas, con dedos y ojos sutiles... Oh, mis pacientes amigos, este libro sólo quiere ser leído por lectores y filólogos perfectos; ; aprended a leerme bien!— Se requiere lectores pacientes, que mantengan las puertas abiertas y no hagan de su lectura un mero descifrar. El lector que el filósofo pide, además de un oído muy fino, poseerá unos dedos y unos ojos sutiles. El lector aprenderá otra mirada que hará olvidar aquella que la figura socrática fijaba en la tragedia. El lector rozará las palabras sutilmente, tal vez sus dedos aprendan a hacer surgir la música y sientan lo intangible, ese espíritu de la música en el que el filósofo asentó su voz.

El imperativo con el que Nietzsche termina el prefacio — «iaprended a leerme bien!»— trae a la memoria el modo doloroso con el que al final de otras obras pregunta: « $i s e$ me ha comprendido?»; « «se me ha oído?», así como las últimas palabras de La gaya ciencia: "Al menos, lo que vais a oír es nuevo; y si no lo entendéis, si lo entendéis mal al cantor, ¡qué importa! En fin, es la 'maldición del cantor'. Tanto más distintamente podréis oír su música y su melodía, tanto mejor podréis bailar —al son que os toca. ¿Queréis?...» Y estas preguntas, así como ese imperativo sorprenden al lector, y de nuevo los puntos suspensivos inician una pausa en la que se puede pensar otra vez lo leído, lo comprendido. El lector vuelve a leer, a escuchar y se pregunta sin duda, si acaso no es un buen lector, un buen oyente, si acaso está danzando sin saberlo. El cantor parece difícil de entender, de ser oído, pero tal vez encierra más peligro esa danza imperceptible, la inaudibilidad de la música que el cantor instaura en el cuerpo del lector, de ese oído ausente. Y se podría pensar que todo el problema es saber oír y danzar.

La pausa que el filósofo introduce con sus preguntas e imperativos, obligan también al lector a plantearse la escucha de un modo que podría apelar al espíritu de la música. Si el filósofo-cantor afirma que, aún cuando no sea comprendido, el lector podrá danzar según su música y sus melodías, el lector antes de responder al envite del filósofo se podría plantear si acaso su escucha estaba emplazada fuera de ese espíritu de la música que el filósofo proponía. Y para responder, tal vez fuera oportuno recordar qué ocurría cuando la música misma perdía 
su espíritu. Cuando esto acontecía se convertía en música decadente, en música dramática.

La música dramática que no obra dionisíacamente sobre el oyente, es retórica convencional cuando los sonidos se convierten en signos recordatorios que dirigen la mirada hacia la escena. La música fisiológica o música-excitación apelaría a los sentimientos del oyente, sería música para llorar o reír, música que asumiría un uso moralmuscular. Una música que tampoco deja escuchar los sonidos.

Tal vez la pausa que el filósofo instaura avise de estos peligros, de lo que él considera una caricatura dionisíaca. ¿Cómo leer entonces? ¿Cómo escuchar las melodías nietzscheanas?

Estas melodías surgen de un espíritu que no pretendía hacer de la filosofía la música más excelsa, de una mirada que no quería ser solar. Las melodías del filósofo desplazan esa relación que la filosofía platónica estableció con la música, al tiempo que trastocan la identidad que los pitagóricos establecieron entre la esencia de la música y la esencia del mundo.

Esa esencia, que bien podría ser la que encierra la música dionisíaca, es la fuerza dionisíaca que desplaza la pregunta por el logos. Tal vez por ello, en el aforismo 333 de La gaya ciencia se pregunta: «¿Qué significa conocer?» el filósofo recuerda la respuesta que a esta cuestión ofreció Spinoza: «; Non ridere, non lugere, neque detestari, sed intelligere.`. Para inteligir era preciso no reír, no lamentar, no detestar. Nietzsche en cambio, escribirá: «Sin embargo: ¿qué es, en definitiva, este intelligere, sino la forma por la que estas tres cosas se nos hacen perceptibles a un tiempo? ¿Qué es sino el resultado de los impulsos distintos y antagónicos de querer burlarse, lamentarse y renegar?» El filósofo expone entonces que conocer es el resultado de un juego, de una composición o compensación entre reír, lamentar y detestar 26 . El filósofo recuerda al oyente que la razón es un estado de relaciones entre diferentes pasiones y que toda pasión encierra también su quantum de razón.

La pausa que el filósofo instaura, bien podría hacer escuchar al lector ese espíritu de la música inaudible, espíritu inoído porque no

26 Para esta interpretación, ver P. Klossowski, «Nietzsche, le polythéisme et la parodie», en Un si funeste désir, Gallimard, Paris, 1963, pp. 202-204. 
puede ser compartido más que en un estado. El lector-oyente debe encontrar quizás ese estado por sí mismo, realizando las preguntas que pueda forzarse a responder.

No sabemos si el canto del filósofo quería hacer sentir ese espíritu de la música, pero tal vez se pueda afirmar que en esas pausas se oye el silbido de esas palabras-flechas; flechas que un día pertenecieron a Apolo y que ahora atraviesan la oscuridad para hacer del lector un topo.

Tal vez, esas melodías que ya no tejen la dialéctica, esas flechas sonoras, entonen que la tarea de la filosofía es un aprender a excavar con espíritu de bailarín. El filósofo sería entonces, el bailarín que esculpe los sonidos de la aurora. 